ISBN 978-81-933894-1-6

International Conference on Arts, Social Sciences, History and Interdisciplinary Studies

(ASSHIS-2017)

Kyoto (Japan), April. 20-21, 2017

\title{
Migrant Children education in Russia
}

\author{
Liudmila Bukalerova $^{1}$, Marina Moseykina ${ }^{1}$ and Angela Dolzhikova ${ }^{1}$ \\ ${ }^{1}$ RUDN-University, Moscow, Russia
}

\begin{abstract}
The problems of sociocultural adaptation of migrant children and their legal status are important because those children are potential citizens of the Russian Federation. They can influence the political and social processes in the country in the foreseeable future. A balanced Russian migration policy can help children migrants easier to adapt. In Russia, quite a lot of laws have been adopted for this, but not all legal problems have been completely solved. In this article, we identified the problems that require immediate law regulation. The legislative experience of various entities of the federation is analyzed. They try within their competence to solve these problems. It is shown what norms of the regions can be taken as a basis for the development of federal laws to improve the state migration policy in the sphere of adaptation and integration of migrant children.
\end{abstract}

Keywords: children, migrant, education in Russia, problems of implementation

\section{Introduction}

Legal status and socio-cultural adaptation of migrant children are of particular importance in the complex issues of regulation of migration processes due to the fact that these are potential citizens of the Russian Federation in the foreseeable future actively influence on political and social processes in the country are of particular importance. Russia entered into the period of mass migration later than the countries of Europe and North America and faces challenges in migration sphere today but has a unique chance to learn from the experience of other EU countries and not to repeat their mistakes.

A sound, balanced migration policy of the state can do much to help migrants and their children easier to pass the sociocultural adaptation in the host country. Russia has done a lot for it but not all problems are fully resolved.

Moving to another country leads to invariably the emergence of social problems for migrants including their children who may experience physical, mental, and educational challenges in adapting to a different environment and culture. Mass migration has a serious impact not only on migrants but on living in it citizens, on economic, political, cultural, intergroup and interethnic relations and educational space.

As of 2015 there are about 221.8 thousand children under the age of 18 years of 4.7 million migrants in Russia. Only schools in Moscow have about 25 thousand children. In 2013, a survey of Muscovites showed that $35 \%$ of their children attended school with children of migrants and $18 \%$ went with them to kindergarten. It is important that education is the most massive available institution providing adaptation of migrant children because it shows them the host country's culture, ensures their social and professional mobility. 


\section{Discussion}

Legal regulation of migrant children in Russia is based on international instruments governing primarily issues of education for migrant children.

So, on 01.08.1975 in Helsinki Russia signed the final act of the conference on security and cooperation in Europe where agreed to ensure children of migrant workers residing in the host country, and access to the country's education on the same conditions as for the children of this country, and in addition let the teaching of native language, national culture, history and geography and in 1992 Russia signed "The world declaration on the survival, protection and development of children" adopted in New York on 30.09.1990.

Separately, it is necessary to note the adoption of several important acts by Russia together with former USSR countries: Decision of Council of heads of CIS States "On proposals for a coordinated migration policy of the States-participants of CIS" (05.10.2007 Dushanbe). It guarantees the state support for the social protection of migrants and members of their families, creation of conditions for education of migrant workers' children in educational institutions of the country. A Convention on the legal status of migrant workers and members of their families of States-members of Commonwealth of Independent States was concluded in Chisinau on 14.11.2008, article 7 of it emphasizes that migrant workers and members of their families will have the right to education in particular (The website of the parliamentary Assembly of the organization of Agreement on collective security http://www.paodkb.ru).

In the Report of the Commissioner on human rights in the Russian Federation for the year 2015 indicated that there were 9924726 foreign nationals on the territory of the Russian Federation as of the 1st of January 2016. More than 17 million foreign nationals entered on the territory of the Russian Federation in 2015; the largest share (55.6 per cent) in the number of arrivals of migrants still belongs to citizens of Ukraine, Uzbekistan, Kazakhstan and Tajikistan. The migration processes caused by the radicalization of the civil conflict that began in Ukraine in 2014 are on particular concern. More than 1.1 million persons from Ukraine entered on the territory of the Russian Federation only in the period from the 1st of April 2014.

In the second half of 2015 there was a tendency to reduce their numbers and on the 1st of January 2016 foreign people on the territory of the Russian Federation were 9.5\% less than on the 1st of January 2015. This can be explained by the fact that the procedure for their legalization is extremely complicated. The lack of legal status entails the expulsion of an immigrant from Russia (The report of the Commissioner for human rights in the Russian Federation for 2015 // https://rg.ru/2016/03/24/ombudsman-doklad-dok.html).

The report of the Ombudsman under the RF President on the rights of the child "protection of children's rights in the Russian Federation" for 2015 says on the 1st of February 2016, the indicator of availability of preschool education for children aged 3 to 7 years on average in the Russian Federation was of 99.23\%.

In order to work with the children of migrants, first of all we must know exactly how many of them because the problem for the schools and the city as a whole is integration/not integration of migrants, the statistics should be conducted not just by citizenship status but several more complex indicators which are actually necessary for the understanding of the situation: the country of origin, native language, length of stay in the Russian Federation. The main body dealing with the migration situation is the Ministry of internal Affairs of the Russian

Federation, so it has the most complete and timely data. However, the Ministry of internal Affairs of the Russian Federation considers only the adult population but not minor children.

In the Decree of the RF Government from 17.11.2008 № 1662-P "About the concept of long-term socioeconomic development of the Russian Federation for the period till 2020" it is said to provide opportunities for every child prior to entering first grade to master programs of preschool education and to fully communicate in the language of instruction. Forecast of long-term socio-economic development of the Russian Federation for the period till 2030 has been developed by the Ministry of economic development declares that it provides $100 \%$ accessibility of preschool education for children aged three to seven years and this data includes the increase in the proportion of children of migrant workers. 
Article 5 of the Federal law from 29.12.2012 № 273-FZ "On education in the Russian Federation" guarantees the right for every individual to education regardless of gender, race, nationality, language, origin and other circumstances.

Admission of children education is carried out in accordance with the Order of admission for educational programs of preschool education (Ministry of education of Russia from the 8th of April 2014 № 293, registered by Ministry of justice of Russia on 12th of May 2014, registration № 32220) which states that the admission of foreign citizens and individuals without citizenship including compatriots abroad in the educational organization at the expense of budgetary appropriations of the Federal budget, budgets of constituent entities of the Russian Federation and local budgets. Thus, children of migrant families can be enrolled if places in preschool are available. The register of children for educational programs of preschool education is organized in accordance with the Letter of the Ministry of education of Russia from 01.12.2014 № 08-1908. However, there is nothing said about the children of migrants in this document, we believe that state accounting is necessary of such children and especially who are the most in need of preschool education.

Letter of the Ministry of education of Russia from 09.07.2014 № 08-859 "On the education of children arriving from the territory of Ukraine" stipulates that with a purpose of the adoption of priority measures for ensuring the rights of children arriving from the territory of Ukraine having the status of refugee, forced migrant or temporarily residing in the territory of Russia to receive public and free pre-school, primary general, basic general and secondary general education in educational institutions of the Russian Federation.

However, according to various survey of CYS, only $15-25 \%$ of the migrant children in Russia go to kindergarten and the share of Russian preschool children enrolled in kindergartens ranges from 50 to $80 \%$ (depending on region) [1].

The reason for this situation is due both to the lack of places in kindergartens and with the lack of information about the procedure of setting the kids in place, with the absence of migrants' funds to pay for the garden, with the difficulties of collecting documents for children including the need for registration of parents and the requirement to buy special medical insurance[2].

Only in schools and kindergartens of Moscow about 28 thousand children do not have Russian citizenship and about 15 thousand of which do not speak Russian. For children who speak bad in Russian an expanded program of teaching the Russian language is provided.

Considerable attention to the Moscow Government is paid to the education and socio-cultural adaptation of migrant children. Thus, the Decision of the government of Moscow from 25.03.2008 № 195-PP "Strategy of the government of Moscow for implementation of the state policy in interests of children "Moscow children" for 2008-2017" states that currently about 25 million of these children study at educational institutions by the most conservative estimates. Most of them is characterized by a weak knowledge of the Russian language, lack of sufficient socialisation of knowledge about the basics of the Russian legislation, culture, history, traditions and standards of behavior in everyday life. In order to create conditions for the integration of such children into the educational environment of Moscow 243 working group to study the Russian language on the basis of 152 schools. About 3 thousand children study in these groups. Training of Russian language teachers has been organized to work with migrant children.

In many Russian regions, in particular, in Moscow the problem of the Russian language is tried to solve with the help of extra classes. So if the child is fluent in language but not enough and if it is difficult without additional support to engage in the educational process then for such children special groups - RAF - Russian as a foreign language are opened in the second half of the day. Those who do come with zero knowledge (and the first graders who did not attend kindergarten in Russia and senior high school students who have not studied in Russian schools at home) are in need of training in the Russian language. Structural units of general education schools - "school of Russian language" were opened in Moscow for them, organized by the Department of education of the Government of Moscow. 
Violation of the right to education of migrant children is strictly punishable under Russian law. So, administrative claim of D. was granted by Supreme court of Republic Kalmykia from 26.01.2016 in case № 3320/2016. D. referred to the fact that the decision of the immigration authority violated the right of children to receive education in the Russian Federation, the right of residence together with parents which is the invasion of privacy and a violation of international law and norms of the Russian legislation.

D. appealed to the court with this claim citing the following facts. On the 9th of September 2015, he appealed to the Department OFMS in the Republic of Kalmykia in Elista with a statement on the extension of the period of temporary stay of his three children who are not citizens of the Russian Federation.

D. was not a citizen of the Russian Federation but had the right to permanent residence in the Russian Federation. He officially worked in the Republic of Kalmykia from April 2013. The children's mother also was not a citizen of the Russian Federation but had a temporary residence permit in the Russian Federation for the period until 10th of April 2018. The period of stay of children had expired on the 6th of September 2015, a statement on the extension of the residence he applied in the prescribed manner. D asked to recognize illegal and to cancel the decision of the head of Department OFMS in the Republic of Kalmykia in the city Elista from the 9th of September 2015 on refusal in prolongation the term of temporary stay of three children to oblige the Department OFMS in the Republic of Kalmykia in Elista to consider the application on prolongation the term of stay in Russia. The Supreme court of the Republic of Kalmykia granted D's claim.

It is necessary to specify that no criminal case was considered by the Russian courts on the issue of bribery by migrant parents for admission of children to school, kindergarten or University.

The problem could be with the children only of illegal migrants due to the lack of documents about their legal presence on the territory of Russia. It is important that Russia has all the conditions for the integration of migrants. However, there is evidence that there are up to 5 million illegal immigrants at present in Russia and some with families. No desire of parents to obtain relevant documents for legal presence in Russia creates difficulties for the education of children of illegal migrants.

Foreign nationals according to the Federal law from 25.07.2002 № 115-FZ "On legal status of foreign citizens in the Russian Federation" must register at migration service, the children of migrants illegally staying in Russia are subject to deportation. Illegally minor children in Russia have no rights including the right to education but it is the fault of their parents who do not want to be legalized in Russia and thereby breaking the law themselves violate the rights of their children.

Another problem that should be recognized when children of migrants have to leave every 90 days with their parents as according to article 5 of the Federal law from the 25th of July 2002 № 115-FZ "On legal status of foreign citizens in the Russian Federation" the period of temporary stay in the Russian Federation a foreign citizen arriving to the Russian Federation in the order not requiring a visa cannot exceed ninety days. Thus can be seen some violation of the rights of migrant children who are forced to interrupt their study every 90 days and leave with their parents. Is not a regulatory act, the response of the Department on organization of work with foreign citizens of the FMS of Russia from the 29th of April 2014 № MS-5/3-29515 " On examination of applications" which "territorial bodies of the FMS of Russia recommended in the case of treatment of foreign nationals or the host party to extend the period of stay of family members of a foreign citizen arriving to the Russian Federation in the order not requiring a visa and received a work permit or patent for the duration of the relevant allowing documents". However, we believe the problem should be resolved by the law, in this regard, we consider it necessary to amend claim 1.1. in article 5 of the Federal law "On legal status of foreign citizens in the Russian Federation" and to read as follows: "the Period of temporary stay in the Russian Federation of a foreign citizen with a patent and the period of temporary stay in the Russian Federation of his family members is determined by the validity of the patent".

The educational orientation of migrant children plays an important role in shaping their future social way. One of the studies was devoted to the attitudes of high school graduates to receive higher education (research in 
three regions of Russia with a small sample of 411 students and 330 parents). Quite a large number of the respondents planned to enter the University and most of them were going to enter to state universities[3].

Article 5 of the law of Moscow from 10.03.2004 № 14 "On general education in Moscow" provides for the existence of specialized educational institutions with ethno-cultural (national) component (Latvia, Armenia, etc.), so there are such kindergartens and schools in Moscow.

\section{Conclusion}

It is necessary to form the framework of the current legislation database on children which focused on the educational needs of children (including individual academic work and achievement) providing interaction of this base with the bases formed in other structures. Development and implementation of mechanisms to identify children who are not enrolled in secondary school (children engaged in vagrancy, the children of migrants) and their preparation for school. You can use the electronic data of registry offices, Ministry of interior, agencies and bodies of local self-government.

A major problem in the field of regulation and control of migration is departmental isolation, only several ministries (the Ministry of internal Affairs of Russia, the Russian Ministry of labour and Ministry of education and science) involved in adaptation and integration of migrants at the Federal level but none of them is the head coordinator in addressing these problems which lead to imbalances in the actions of the Federal agencies, the regions of the Russian Federation, institutions of culture and education, and as a consequence do not lead to effective implementation of the concept of state migration policy of the Russian Federation for the period till 2025, the national security Strategy of the Russian Federation and other acts. Accordingly, there is not still a clear strategy of the state migration policy in the sphere of adaptation and integration of migrants.

\section{References}

[1] Arefiev, A. L. The education of children from families of foreign citizens in the schools of Moscow, Vestnik RUDN. Series: education Issues. Languages and profession. 2015. № 5. pp. 149-160.

[2] Yu. Florinskaya. Children of migrants in Russia: access to education and medicine. Available: http://www.demoscope.ru/weekly/2012/0515/analit02.php

[3] The situation of migrant children in St. Petersburg. United Nations Children's Fund, (UNICEF), 2011. p.166. 